\title{
Reduction of nitrite-ions in water over Pd-supported on structured fibrous materials
}

\author{
V. Höller, K. Rådevik, I. Yuranov, L. Kiwi-Minsker, A. Renken* \\ Swiss Federal Institute of Technology, EPFL-LGRC, CH-1015 Lausanne, Switzerland \\ Received 14 October 2000; received in revised form 17 December 2000; accepted 22 December 2000
}

\begin{abstract}
The catalytic hydrogenation of nitrite in water to nitrogen over Pd-supported on different woven fibrous materials is studied. Low porosity carbon fibers, low porosity D-type glass fibers and composite (glass covered by $\gamma$-aluminia) fibers are used. The dispersion of Pd is compared for different supports at various Pd-loadings and correlated with the catalytic activity. The ammonia as an undesired by-product was also observed and the main parameters suppressing its formation are discussed. A reactor concept based on woven fibrous catalysts is suggested and the main design parameters for the technical application are estimated. () 2001 Elsevier Science B.V. All rights reserved.
\end{abstract}

Keywords: Fibrous catalyst support; Support material; Pd-catalyst; Pd-dispersion; Catalytic nitrite hydrogenation

\section{Introduction}

The nitrate- and nitrite-ions removal from ground water is becoming an environmental problem of major concern due to their high toxicity. Conventional physicochemical methods, like ion exchange, reverse osmosis and electrodialysis allow effective removal of nitrate/nitrite ions concentrating them, but do not generally achieve their complete disposal. The most environmentally benign methods are based on selective reduction of nitrate/nitrite to nitrogen by microorganisms or catalytically over noble metals [1-8]. The biological process is slow, complex and requires sometimes a costly post-treatment of effluents. In the recent publication by Lecloux [8], a two-step process to reduce nitrate-ions in water was suggested. In the first step, nitrate ions are mainly transformed

${ }^{*}$ Corresponding author. Tel.: +41-21-693-31-81; fax: +41-21-693-31-90.

E-mail address: albert.renken@epfl.ch (A. Renken). in nitrite over $\mathrm{Pd} / \mathrm{Cu}$-based catalyst, and in the second step, nitrite is decomposed to $\mathrm{N}_{2}$ on a Pd catalyst, the carrier being the same for both catalysts.

The main problem associated with the catalytic reduction is an ammonia formation (undesired by-product) and a growth of bacteria. Moreover, during the reduction hydroxide ions are formed increasing the $\mathrm{pH}$ and leading to a $\mathrm{pH}$ gradient along the catalyst pores. It has been observed that the overall kinetics is strongly $\mathrm{pH}$ dependent: both the reaction rate and selectivity towards nitrogen formation decrease with increasing $\mathrm{pH}$ value. It is important to note that the external and internal diffusions remain significant for catalyst particles larger than $100 \mu \mathrm{m}$. In order to avoid transport limitations within the pores and consequently a lose of selectivity, catalytic particles of small size have to be used $[3,4,8]$. In a technical application, the minimal size of these particles is, however, limited by the filtration of catalyst powder from the liquid after the reaction. To overcome this problem Hähnlein et al. [9] suggested incorporating 


\begin{tabular}{|c|c|}
\hline \multicolumn{2}{|c|}{ Nomenclature } \\
\hline AGF & D-type glass fiber covered with $\gamma-\mathrm{Al}_{2} \mathrm{O}_{3}$ \\
\hline$c$ & concentration $\left(\mathrm{mg} \mathrm{l}^{-1}\right)$ \\
\hline $\mathrm{CF}$ & carbon fiber \\
\hline$d_{\mathrm{p}, \mathrm{Pd}}$ & $\begin{array}{l}\text { calculated diameter of Pd clusters on } \\
\text { fibrous support }(\mathrm{nm})\end{array}$ \\
\hline DGF & D-type glass fiber \\
\hline$k$ & reaction constant $\left(1 \mathrm{~min}^{-1} \mathrm{~g}_{\mathrm{Pd}}{ }^{-1}\right)$ \\
\hline$M$ & molar mass of nitrite $\left(\mathrm{g} \mathrm{mol}^{-1}\right)$ \\
\hline$N_{\mathrm{A}}$ & Avogadro' constant (atoms mol ${ }^{-1}$ ) \\
\hline & surface per Pd-atom ( $\mathrm{nm}^{2} / \mathrm{Pd}$-atom) \\
\hline SSA & $\begin{array}{l}\text { specific surface area (BET method) } \\
\left(\mathrm{m}^{2} \mathrm{~g}^{-1}\right)\end{array}$ \\
\hline SSAPd $_{P}$ & specific surface of $\mathrm{Pd}\left(\mathrm{m}^{2}{ }_{\mathrm{Pd}} \mathrm{g}_{\mathrm{Pd}}{ }^{-1}\right)$ \\
\hline$X$ & conversion \\
\hline$v_{\mathrm{t}}$ & turnover frequency $\left(\mathrm{s}^{-1}\right)$ \\
\hline \multicolumn{2}{|c|}{ Subscripts } \\
\hline $\mathrm{Pd}$ & palladium \\
\hline 0 & initial \\
\hline
\end{tabular}

the fine catalyst particles into hollow fibers of an inner diameter of $200 \mu \mathrm{m}$. Daub et al. [10] used catalytic membranes for the reduction of nitrate. As far as the reactor design is concerned, a plug-flow reactor with a very limited back-mixing, is recommended as the best reactor type in order to improve the selectivity of the process [8].

To avoid separation problems and a back-mixing, and to generate an efficient gas/liquid/solid three-phase contact, we suggested to use woven fibrous catalysts for the reactors with structured catalytic beds in three-phase reaction engineering [11-14]. Pd- and $\mathrm{Pd} / \mathrm{Cu}$-supported on woven glass fibrous materials have been already tested for the catalytic nitrite-nitrate reduction and demonstrated an appreciable activity $[15,16]$. The main problems for their technical application are a too important ammonia formation and a low resistance to mechanical stress during passage of liquid-phase.

The objective of the present work is to evaluate new woven fibrous materials, like low porosity carbon, low porosity glass and new composite glass/oxide ceramic fibers as catalytic supports in respect to their technical application in nitrite reduction. We concentrate here on the investigation only of nitrite reduction since this process appears to be a limiting step in the fully catalytic and combined bio-catalytic denitrification of water recently reported by Lecloux [8]. According to his results, the biomass produced under the conditions used for nitrate reduction over $\mathrm{Pd} / \mathrm{Cu}$ catalyst, is able to selectively decompose $\mathrm{NO}_{3}{ }^{-}$ions to $\mathrm{NO}_{2}{ }^{-}$-ions, with the activity being 5-10 times higher than $\mathrm{Pd} / \mathrm{Cu}$ catalyst and with a very limiting formation of ammonia. Therefore, the investigation of the intrinsic kinetics of the nitrite hydrogenation over Pd-supported on different fibrous materials is aimed on an increase of selectivity towards $\mathrm{N}_{2}$ formation avoiding ammonia production. A novel concept of the reactor with structured fibrous catalytic bed is evaluated in respect to its application to water denitrification.

\section{Experimental}

\subsection{Catalyst preparation and characterization}

Carbon fibers (CF) and D-type glass fibers (DGF) in the form of fabrics were used for the catalyst preparation as received. All fabrics were woven from the threads consisting of a bundle of filaments (diameter of $\sim 5 \mu \mathrm{m}$ ) with a specific surface area (SSA) of $2 \mathrm{~m}^{2} \mathrm{~g}^{-1}$, which corresponds to the geometric surface of the filaments.

The composite ceramic-like fibrous support (AGF) were prepared from D-type glass fabrics by treating them first in boiling aqueous $\mathrm{HCl}$ solution $(3.7 \%)$ in order to create surface roughness. After rinsing the fabrics in distilled water, the aluminum hydroxide was deposited via precipitation from $\mathrm{Al}\left(\mathrm{NO}_{3}\right)_{3}$ aqueous solution followed by calcinations in air at $550^{\circ} \mathrm{C}$. This procedure results in a formation of thin $\gamma$-alumina layer $(6 \mathrm{wt} . \%)$ on the glass filaments as confirmed by X-ray. Thus, the AGF presents a novel composite fibrous support with characteristics close to ceramic demonstrating increased mechanical and thermal stabilities $\left(<800^{\circ} \mathrm{C}\right)$, if compared to the porous glass fiber supports $\left(<400^{\circ} \mathrm{C}\right)$.

$\mathrm{Pd}$ as an active component was deposited via impregnation from aqueous solution of palladium(II) acetate (purum, Fluka Chemie AG, Buchs Switzerland). The Pd-loading was varied from 0.3 to $5 \mathrm{wt} . \%$. Before the reaction, the catalysts were reduced by a sodium formate (HCOONa) aqueous solution (10wt.\%) at $80^{\circ} \mathrm{C}$. 

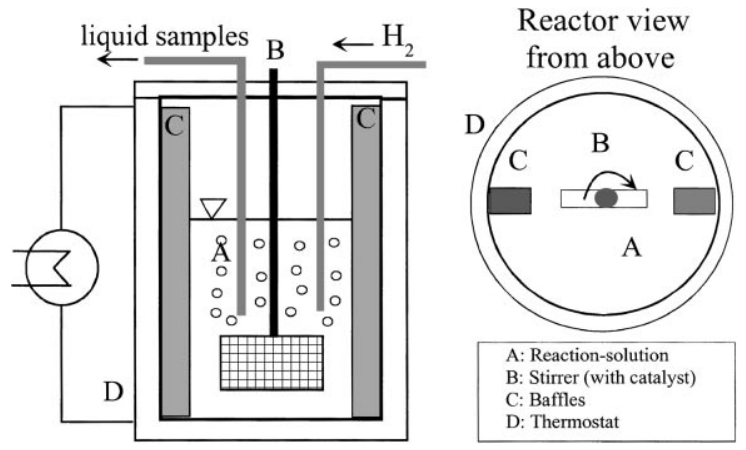

Fig. 1. Experimental set-up for hydrogenation of nitrite over Pd-based fibrous catalysts.

\subsection{Experimental set-up and procedure}

The kinetic experiments and testing of catalytic activity/selectivity were carried out in a temperature controlled batch reactor (21 glass vessel), equipped with $\mathrm{H}_{2}$ inlet, a sampling port and two baffles to insure an effective mixing. The experimental set-up is schematically presented in Fig. 1. The catalysts were placed between two metal gauzes $(60 \mathrm{~mm} \times 45 \mathrm{~mm})$ fixed on a stirrer. The amount of catalyst corresponded to the total amount of $\mathrm{Pd}$ between 7 and $15 \mathrm{mg}_{\mathrm{Pd}}$. The agitation speed was kept at $420 \mathrm{rpm}$. Diffusion limitations can be excluded since the rate of nitrite decomposition and the selectivity to nitrogen were independent from the agitation speed for a stirrer velocity higher than $420 \mathrm{rpm}$ (varied from $420 \mathrm{rpm}$ up to $800 \mathrm{rpm}$ ) over two types of the catalysts, $1 \%-\mathrm{Pd} / \mathrm{CF}$ and $2 \%-\mathrm{Pd} / \mathrm{AGF}$. The temperature was kept at $293 \mathrm{~K}$, except the experiments of the activity/selectivity temperature dependence. The $\mathrm{pH}-6$ was kept constant during all experiments, set-up by a phosphate buffer $(50 \mathrm{mM})$. The saturation of the buffer solution with hydrogen was started $30 \mathrm{~min}$ before each experiment and was continued till its end, by bubbling hydrogen $\left(200 \mathrm{ml} \mathrm{min}^{-1}\right)$ through the solution under stirring. The reaction was started by adding a concentrated $\mathrm{NaNO}_{2}$-solution to the 1.51 buffer, which resulted in an initial nitrite concentration of $10 \mathrm{mgl}^{-1}$. Samples were periodically taken and analyzed for $\mathrm{NO}_{2}{ }^{-}$and ammonia concentration via spectrometer Nova 60 (Merk). For determination of nitrite, the Griess' reaction (absorbance maximum at $525 \mathrm{~nm}$ ) and for ammonia the Berthelots's reac- tion (absorbance maximum at $690 \mathrm{~nm}$ ) were used [17]. The $\mathrm{pH}$ values were monitored by a Metrom$632 \mathrm{pH}$-meter equipped with an Aquatrode electrode.

The turnover frequency $v_{t}$ gives the number of revolutions of the catalytic cycle per unit time and per number of active sites [18] and is calculated for first-order kinetics as follows:

$v_{\mathrm{t}}=\frac{k_{\text {Nitrite }} \cdot c_{\text {Nitrite }} \cdot S_{\mathrm{Pd}} \cdot N_{\mathrm{A}}}{\mathrm{SSA}_{\mathrm{Pd}} \cdot M_{\text {Nitrite }}}$

where $k_{\text {Nitrite }}$ is the rate constant, $c_{\text {Nitrite }}$ the nitrite concentration, $S_{\mathrm{Pd}}$ the surface occupied by one Pd-atom $\left(0.0787 \mathrm{~nm}^{2}\right), N_{\mathrm{A}}$ the constant of Avogadro, SSAPd the specific surface area of $\mathrm{Pd}$ and $M_{\text {Nitrite }}$ is the molar mass of nitrite.

\subsection{Catalyst characterization}

The BET SSA was determined by $\mathrm{N}_{2}$ adsorptiondesorption measured at $77 \mathrm{~K}$ via Sorptomatic 1990 (Carlo Erba). The samples were pre-treated under vacuum at $250^{\circ} \mathrm{C}$.

The specific surface area of $\mathrm{Pd}\left(\mathrm{SSA}_{\mathrm{Pd}}\right)$ - and $\mathrm{Pd}$-dispersion were measured by pulse adsorption of $\mathrm{CO}$ (3\% CO in helium) performed at $323 \mathrm{~K}$ via Micromeritics 2910 (Micromeritics, USA) equipped with a mass-spectrometer and on-line gas chromatography. The samples were pre-treated in a flow of hydrogen at $623 \mathrm{~K}$ for $120 \mathrm{~min}$, followed by a $60 \mathrm{~min}$ treatment in $\mathrm{He}$ at $623 \mathrm{~K}$ to decompose $\mathrm{PdH}$. A stoichiometry of $\mathrm{CO} / \mathrm{Pd}=0.6$ and a $\mathrm{Pd}$ surface density of $1.2 \times 10^{19}$ atoms $\mathrm{m}^{-2}$ was used for the SSAPd calculations.

\section{Results and discussions}

\subsection{Pd-dispersion on fibrous catalysts}

In Table 1, the Pd-dispersion of the tested catalysts is presented. The influence of different supports (CF, DGF and AGF) can be compared for the same Pd-loading of $1 \%$. The dispersion on the AGF-support was found to be about $60 \%$ higher compared to the CF-support and 20\% higher compared to the DGF-support. The variation of the Pd-loading on a AGF-support showed that a decrease from 5 to 0.3 wt.\%-Pd leads to a 10-fold higher Pd-dispersion and consequently SSAPd. 
Table 1

Characteristics of Pd-based catalysts for different fibrous supports and various Pd-loadings

\begin{tabular}{llllrr}
\hline Support & BET-SSA $\left(\mathrm{m}^{2} \mathrm{~g}^{-1}\right)$ & Pd-loading $(\%)$ & $d_{\mathrm{p}, \text { Pd }}(\mathrm{nm})$ & Dispersion of Pd $(\%)$ & $\mathrm{SSA}_{\text {Pd }}$ of Pd $\left(\mathrm{m}^{2}{ }_{\text {Pd }} \mathrm{g}_{\text {Pd }}-1\right)$ \\
\hline CF & 40 & 1.0 & 49.9 & 2.2 & 10.0 \\
DGF & 6 & 1.0 & 35.1 & 3.2 & 14.2 \\
AGF & 14 & 5.0 & 59.0 & 1.9 & 8.5 \\
AGF & 14 & 2.0 & 33.0 & 3.4 & 15.2 \\
AGF & 14 & 1.0 & 30.0 & 10.8 & 16.7 \\
AGF & 14 & 0.5 & 5.7 & 20.0 & 50.0 \\
AGF & 14 & 0.3 & & 88.0 \\
\hline
\end{tabular}

\subsection{Intrinsic kinetics}

\subsubsection{Influence of the support}

The catalytic behavior of the samples summarized in Table 1 was studied in the hydrogenation of nitrite. The dependency of nitrite and ammonia concentrations on time for the catalysts with Pd (1wt.\%) on different fibrous supports were obtained. Typical reaction profiles are shown in Fig. 2. Over all catalysts the depletion of nitrite follows a first-order decay

$$
\frac{C_{\text {Nitrite }}}{C_{\text {Nitrite }, 0}}=\exp \left(-k_{\text {Nitrite }} \cdot t \cdot c_{\mathrm{Pd}}\right)
$$

Ammonia production was observed from the beginning of the reaction with an approximately linear increase of the concentration. On the basis of the reaction kinetics shown in Fig. 2, the main characteristics of the fibrous catalysts are defined for evaluation of their performance: (i) the rate constant $k_{\text {Nitrite }}$; (ii) the turnover frequency $v_{\mathrm{t}}$; (iii) the initial reaction rate at a nitrite concentration $c_{\text {Nitrite }}=10 \mathrm{mgl}^{-1}$; (iv) the concentration of ammonia at a given conversion. It was assumed that nitrogen and ammonia are the only reaction products.

The type of the fibrous support was found to influence strongly the specific catalytic activity and ammonia formation. $\mathrm{Pd}$ on $\mathrm{CF}$ demonstrated the lowest activity. The rate constant $k_{\text {Nitrite }}$ (see Fig. 3) is about a half of the value found for the Pd on DGF, whereas the ammonia production is more than two times higher. For example, at $X=60 \%$ of nitrite conversion over $\mathrm{Pd} / \mathrm{CF}$ the ammonia concentration is $c_{\text {Ammonia, } \mathrm{CF}}=1.7 \mathrm{mg} \mathrm{l}^{-1}$, while at the same conversion over Pd/DGF, $c_{\text {Ammonia, DGF }}=0.7 \mathrm{mg} \mathrm{l}^{-1}$. Over

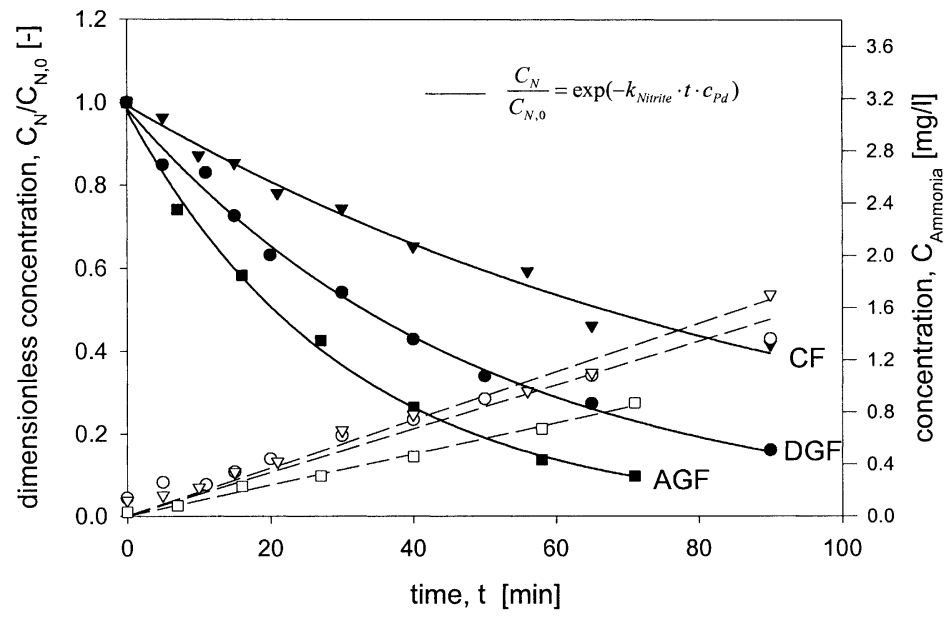

Fig. 2. Nitrite consumption (bold symbols: experiment, line: first-order model) and ammonia formation (open symbols) as a function of reaction time over Pd $(1 \mathrm{wt} . \%)$ supported on: CF $\left(c_{\text {Nitrite }, 0}=10.9 \mathrm{mg}_{\text {Nitrite }} 1^{-1}\right)$, on DGF $\left(c_{\text {Nitrite, } 0}=10.6 \mathrm{mg}_{\text {Nitrite }} 1^{-1}\right)$ and on AGF $\left(c_{\text {Nitrite }, 0}=9.9 \mathrm{mg}_{\text {Nitrite }} 1^{-1}\right)$. 


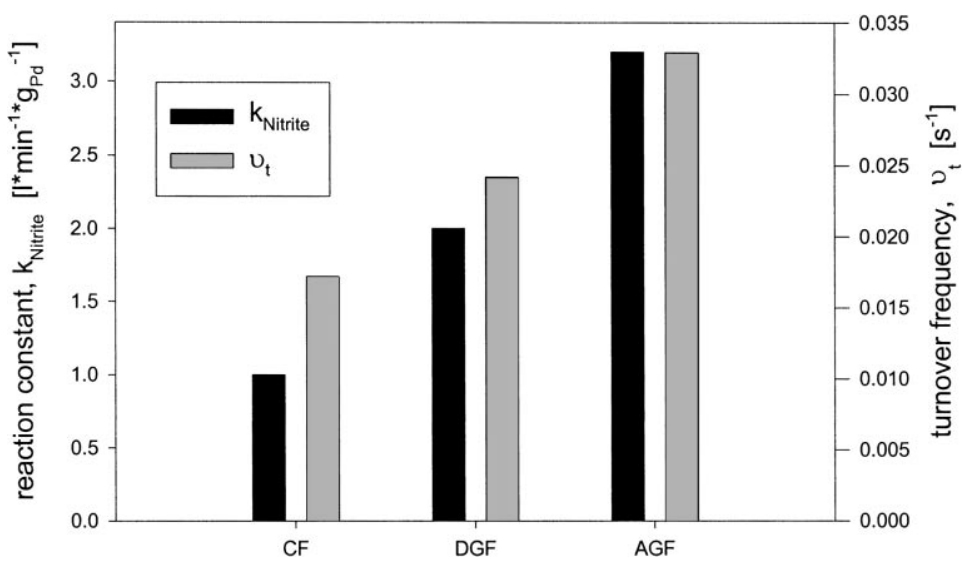

Fig. 3. Reaction constants $k_{\text {Nitrite }}$ and turnover frequency $v_{\mathrm{t}}$ obtained over Pd (1wt.\%) supported on CF, DGF and AGF.

Pd-supported on AGF a further increase in activity and selectivity to nitrogen is observed (at $X=60 \%$, $c_{\text {Ammonia }, \mathrm{AGF}}=0.3 \mathrm{mg}^{-1}$ ).

In order to elucidate the influence of the support composition on the activity of the supported Pd, the values of turnover frequency $v_{\mathrm{t}}$ were calculated. In Fig. 3, the reaction constants $k_{\text {Nitrite }}$ and turnover frequencies $v_{\mathrm{t}}$ are displayed. Although the trend of both parameters is the same, an influence of the Pd-dispersion is eliminated by comparison of the turnover frequency $v_{\mathrm{t}}$ values since the rate of nitrite depletion is referred to the Pd surface and not to Pd amount. Thus, the differences in the turnover frequency $v_{\mathrm{t}}$ are assigned to the nature of the support. The highest turnover frequency was obtained for the Pd-supported on AGF confirming the positive effect of alumina-support on catalytic properties of metallic Pd being in line with the results reported by Vorlop et al. [2].

In order to elucidate the influence of the fibrous support on the Pd activity, the reaction rate of the Pd-supported on AGF was compared with the activity observed over Pd-supported on pure silica glass fibers (SGF) reported by Matatov-Meytal et al. [15]. The reaction rates $r$ were calculated based on the kinetic parameters determined. At a concentration of nitrite $c_{\text {Nitrite }}=10 \mathrm{mg} \mathrm{l}^{-1}$ over the $1 \%-\mathrm{Pd} / \mathrm{AGF}$ a seven-fold higher reaction rate $\left(r=80 \mathrm{mg} \mathrm{min}^{-1} \mathrm{~g}_{\mathrm{Pd}}{ }^{-1}\right)$ was found, if compared to the rate reported for $\operatorname{Pd}(0.1 \%) / \mathrm{SGF}\left(r=11.5 \mathrm{mg} \mathrm{min}^{-1} \mathrm{~g}_{\mathrm{Pd}}{ }^{-1}\right)$ [15]. So, alumina/silica composite was shown as the most suitable fibrous support in respect to the activity/selectivity of Pd-based catalyst and was chosen for the further kinetics study.

\subsubsection{Influence of the Pd-dispersion}

It was observed that the Pd-loading on AGF influences strongly the reaction constant $k_{\text {Nitrite }}$ and the ammonia production, as shown in Fig. 4. Decreasing the Pd-loading over one order of magnitude leads to a three times higher reaction constant $k_{\text {Nitrite }}$ and a $50 \%$ lower ammonia production. These results are in line with the observations made by Lecloux [8], who claimed that high Pd-dispersion as an essential parameter to obtain a high activity/selectivity.

In Fig. 5, the reaction constant $k_{\text {Nitrite }}$ and the turnover frequency $v_{\mathrm{t}}$ are plotted versus the Pd-dispersion. A linear increase of the $k_{\text {Nitrite }}$ is due to the increase of the ratio of surface to total $\mathrm{Pd}$-atoms $\left(\mathrm{SSA}_{\mathrm{Pd}}\right)$ with the dispersion. The slight decrease of the $v_{t}$ might be due to the stronger metal-support-interaction (MSI), since a better dispersion results in smaller Pd-particles $d_{\mathrm{p}, \mathrm{Pd}}$ on the support surface (see Table 1).

\subsubsection{Influence of the reaction temperature}

The temperature dependence of the reaction rate constant $k_{\text {Nitrite }}$ and the ammonia production over a $1 \%$-Pd/AGF catalyst is presented in Fig. 6 . The activation energy of $26 \mathrm{~kJ} \mathrm{~mol}^{-1}$ was determined via the Ahrrenius plot (bold symbols). Hörold et al. [19] found over a $0.8 \%-\mathrm{Pd} / \mathrm{SiO}_{2}$ catalyst an activation energy of 


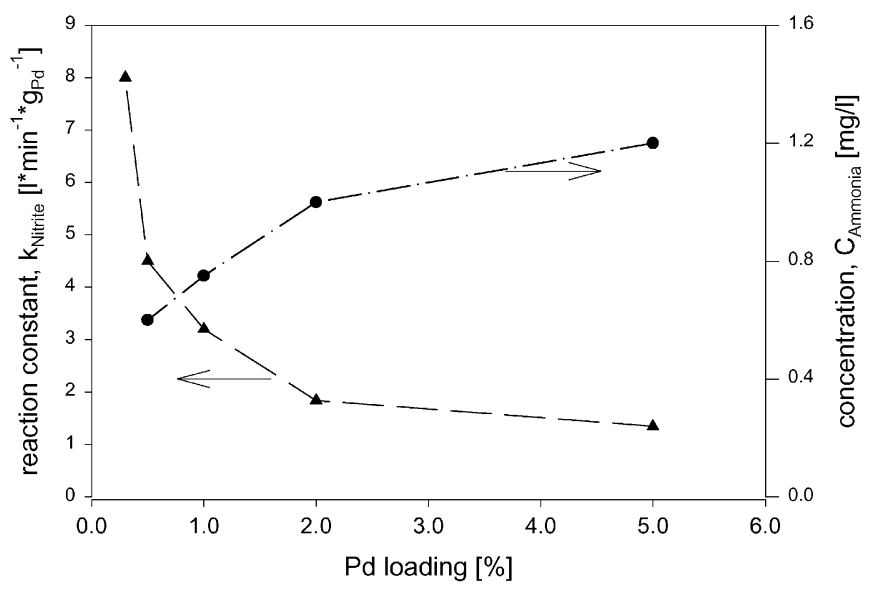

Fig. 4. Reaction constant $k_{\text {Nitrite }}$ and ammonia production ( $c_{\text {Ammonia }}$ at $80 \%$ nitrite conversion) as a function of the Pd-loading.

$30 \mathrm{~kJ} \mathrm{~mol}^{-1}$, being in the same order of magnitude. The production of ammonia was observed to increase slightly with increasing temperature (open points). An ammonia concentration of $0.4 \mathrm{mg} \mathrm{l}^{-1}$ at $281 \mathrm{~K}$ was obtained, being below the limit accepted by the drinking water regulations (maximum allowed ammonia concentration is $0.5 \mathrm{mg} \mathrm{l}^{-1}$ ).

An optimization of the catalysts, including chemical composition of the fibrous support, the dispersion of supported Pd [8], and the reaction operating conditions, like hydrogen partial pressure $[3,4]$ could further improve the selectivity towards nitrogen.

\subsection{Reactor design}

During the development of any catalytic process the reactor and catalyst design must be adapted to each other. This requirement becomes especially important when the reaction is diffusion limited. The diffusion limitation, taking place during nitrite hydrogenation, strongly affects the selectivity toward nitrogen since mass transfer limitations increase the contact time of the surface intermediates in the catalytic grain and favour an ammonium-ion formation. From an engineering point of view, a tubular reactor, with a narrow

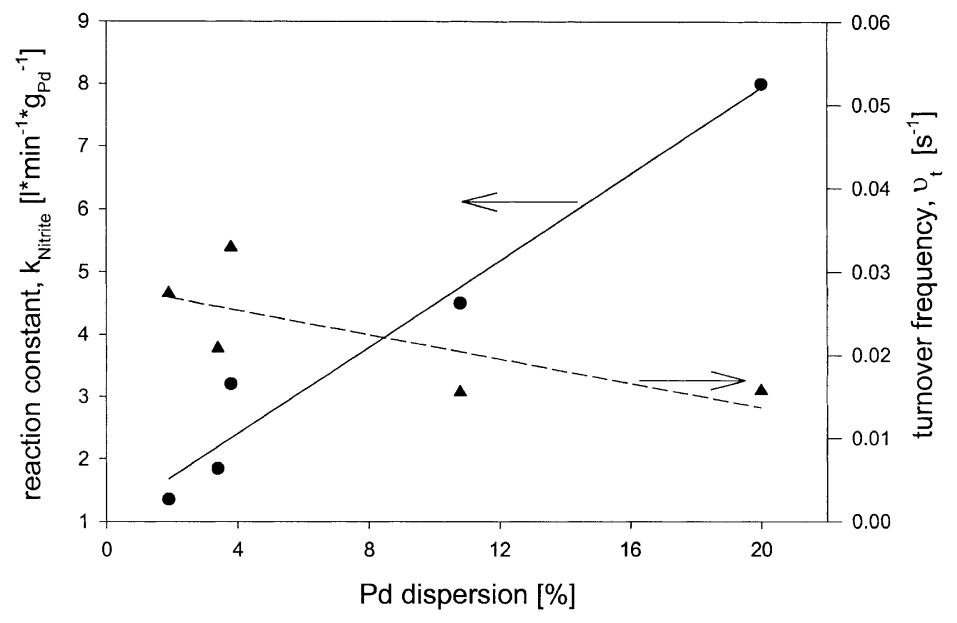

Fig. 5. Reaction constant $k_{\text {Nitrite }}$ and turnover frequency $v_{\mathrm{t}}$ as a function of Pd-dispersion. 


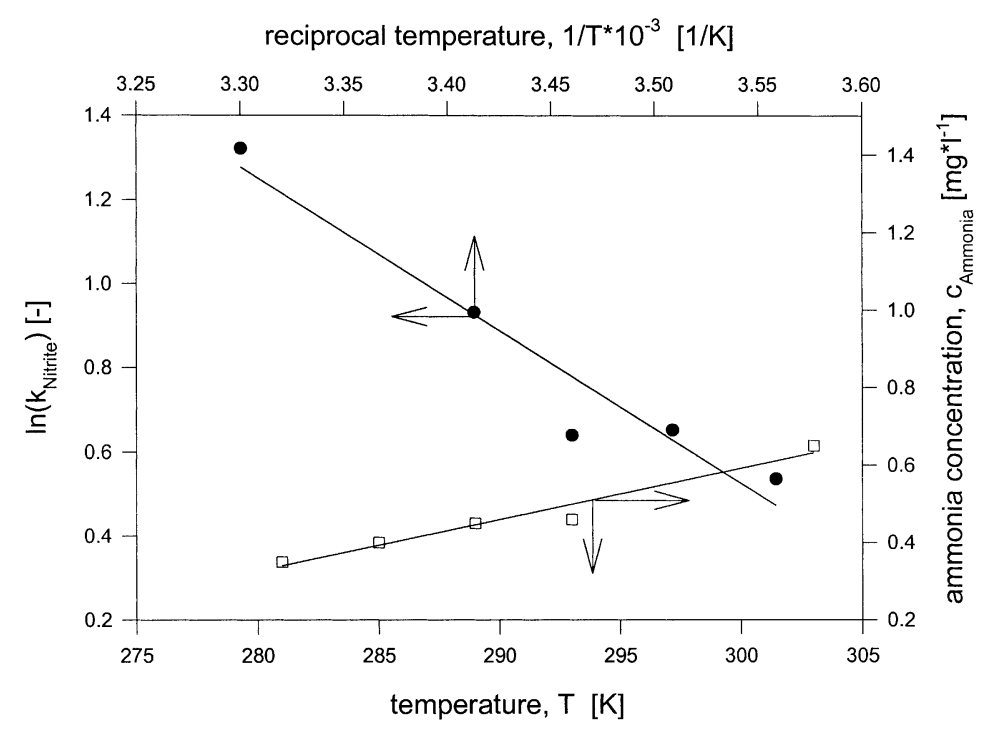

Fig. 6. Temperature dependence of $k_{\text {Nitrite }}$ and the ammonia production (at $75 \%$ conversion) over a $1 \%$-Pd/AGF catalyst.

residence time distribution (RTD), catalytic particles as small as possible and the avoidance of dead zone formation is essential to achieve low ammonia concentrations. Although different reactor modifications have been tried for the pilot plant reactor operated continuously [8], the hydrodynamic behavior is far away from plug-flow. Therefore, a new reactor design for nitrite hydrogenation is warranted.

The lab-scale results reported herein show that Pd-supported on AGF catalysts demonstrate the overall activity and selectivity suitable for the nitrite reduction in water into molecular nitrogen on a pilot-scale. Recently, we suggested to use woven fibrous catalysts for reactors with structured catalytic beds in three-phase reaction engineering [11-14]. One of the designs possible is a multistage-cascaded bubble column, in which the trays are made from fibrous-supported catalysts. This reactor type is schematically presented in Fig. 7. In our previous publications [11-14], several hydrodynamic parameters, like the liquid hold-up and the pressure drop through the bed, were investigated and described by empirical equations. The fabric layers prevent back-mixing and a redistribution of the liquid- and gas-phases at each catalyst layer avoid the formation of dead zones. A narrow residence time distribution is demonstrated.
From the kinetic data obtained over the 1\%-Pd/AGF catalyst an estimation of the dimensions for the staged bubble column can be done. The reactor design was tested in a preliminary experiments carried out in a $24 \mathrm{~mm}$ inner diameter column staged with three $1 \%$-Pd/AGF layers. With a superficial liquid velocity of $1 \mathrm{~cm} \mathrm{~s}^{-1}$ and a superficial gas velocity of $15 \mathrm{~cm} \mathrm{~s}^{-1}$, the activity observed was only $6 \%$ lower compared to the stirred tank reactor described above. Therefore, to decompose $90 \%$ of the nitrite in a $1000001 \mathrm{~h}^{-1}$ wastewater-stream, approximately $130 \mathrm{~kg}$ of catalyst are sufficient. A total of 30 catalytic layers with a distance of $10 \mathrm{~cm}$ between each other placed into

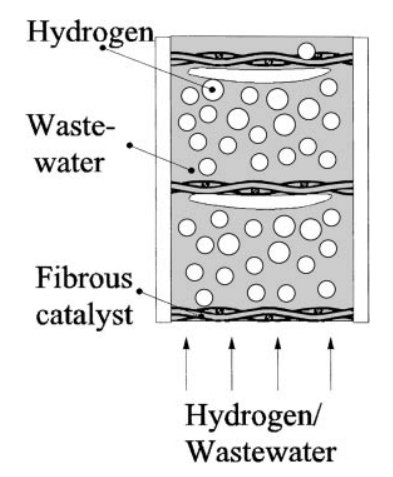

Fig. 7. Bubble column staged with fibrous structured catalysts. 
a reactor with a $3.0 \mathrm{~m}$ diameter would result in a reactor-high of $3 \mathrm{~m}$. It can be concluded that even for high throughputs, as taken in this example, the reactor dimensions are reasonable. To reduce external and internal diffusion resistance, small thread diameters with short diffusion lengths are beneficial especially for high superficial gas and liquid velocities. It should improve a mass transfer, which is known to be of major importance for the reactor design. A detailed hydrodynamics study through the multi-stage-cascaded bubble column is in progress will be reported elsewhere.

\section{Conclusion}

- The catalytic hydrogenation of nitrite ions in water to molecular nitrogen was studied over Pd-based structured fibrous catalysts. Pd-supported on new composite fibrous (glass fibers covered by $\gamma-\mathrm{Al}_{2} \mathrm{O}_{3}$ ) showed the highest activity and selectivity towards nitrogen. The activity was more than seven times higher compared to Pd-supported on silica fibrous glass reported in the literature [15].

- The dispersion of Pd was found to depend on the chemical composition of the support and increased with lower Pd-loading.

- The reaction constant $k_{\text {Nitrite }}$ was found to increase linearly with the Pd-surface. The turnover frequency $v_{\mathrm{t}}$ decreased slightly when the Pd-dispersion increased.

- Ammonia production was observed to diminish slightly with decreasing temperature. For the optimized catalyst the concentration attained at $75 \%$ of conversion was $0.4 \mathrm{mgl}^{-1}$, which below the admissible level for drinking water.

- A novel reactor concept designed as a bubble column staged with fibrous catalytic layers was suggested for the reduction of nitrite to $\mathrm{N}_{2}$ on a pilot-scale. The reactor dimensions estimated were found suitable for a water throughput of $1000001 \mathrm{~h}^{-1}$.

\section{Acknowledgements}

The financial support provided for this work by the Swiss National Foundation, the Swiss Commission for Technology and Innovation and the Max-Buchner Forschungsstiftung is gratefully acknowledged. The authors also would like to thank Dr. D. Boulouchev for the measurements of the Pd-specific surface area, and Mrs. A. Udriot for the preparation of the catalysts.

\section{References}

[1] A. Kapoor, T. Viraraghavan, J. Environ. Eng. 4 (1997) 371.

[2] S. Hörold, K.D. Vorlop, T. Tacke, M. Sell, Catal. Today 17 (1993) 21.

[3] K.D. Vorlop, U. Prüsse, Catalytic removal of nitrite from Water, in: F.K.J.G. Janssen, R.A. van Santen (Eds.), Imperial College Press, London, 1999, p. 195.

[4] A. Pintar, G. Bercic, J. Levec, AIChE J. 44 (1998) 2280.

[5] A. Pintar, M. Setinc, J. Levec, J. Catal. 174 (1998) 72.

[6] G. Strukul, F. Pinna, M. Marella, L. Meregalli, M. Tomaselli, Catal. Today 27 (1996) 209.

[7] U. Prüsse, M. Hähnlein, J. Daum, K.D. Vorlop, Catal. Today 55 (2000) 79.

[8] A.J. Lecloux, Catal. Today 53 (1999) 23.

[9] M. Hähnlein, U. Prüsse, J. Daum, V. Morawsky, M. Kröger, M. Schröder, M. Schnabel, K.D. Vorlop, Preparation of Catalysts VII 118 (1998) 99.

[10] K. Daub, G. Emig, M.J. Chollier, M. Callant, R. Dittmeyer, Chem. Eng. Sci. 54 (1999) 1582.

[11] L. Kiwi-Minsker, I. Yuranov, V. Höller, A. Renken, Chem. Eng. Sci. 54 (1999) 4785.

[12] V. Höller, D. Wegricht, I. Yuranov, L. Kiwi-Minsker, A. Renken, Chem. Eng. Technol. 23 (2000) 251.

[13] V. Höller, D. Wegricht, L. Kiwi-Minsker, A. Renken, Catal. Today 60 (2000) 51

[14] V. Höller, K. Radevik, L. Kiwi-Minsker, A. Renken, Bubble columns staged with structured fibrous catalytic layers: residence time distribution and mass transfer, Ind. Eng. Chem. Res., (2001), in press.

[15] Y. Matatov-Meytal, V. Barelko, I. Yuranov, M. Sheintuch, Appl. Catal. B: Environ. 27 (2000) 127.

[16] Y. Matatov-Meytal, V. Barelko, I. Yuranov, L. Kiwi-Minsker, A. Renken, M. Sheintuch, Cloth catalysts in water denitrification. Part II. Removal of nitrates using $\mathrm{Pd}-\mathrm{Cu}$-supported on glass fibers, Appl. Catal. B: Environ. 2000 , in press.

[17] Handbook of Nova-60, Merk, Dietikon, Switzerland, 1998.

[18] M. Boudart, Chem. Rev. 95 (1995) 661.

[19] S. Hörold, Herstellung, Charakterisierung und Einsatz von Edelmetallkatalysatoren zur Nitrat- und Nitritentfernung in der Trinkwasseraufbereitung, Ph.D. Thesis, Technische Universität Carolo-Wilhelmina zu Braunschweig, Braunschweig, Germany, 1995. 